\title{
Pengembangan Buku Ajar Mata Kuliah Media Pembelajaran Bahasa Indonesia untuk Mahasiswa
}

\author{
Rahmawati Mulyaningtyas \\ Fakultas Tarbiyah dan Ilmu Keguruan, IAIN Tulungagung \\ rahmawatimulyaningtyas@gmail.com
}

DOI: http://dx.doi.org/10.32528/bb.v5i1.3070

Diterima: 02-03-2020

Diterbitkan: 02-04-2020

\begin{abstract}
ABSTRAK
Penelitian ini merupakan penelitian untuk mengembangkan buku ajar mata kuliah media pembelajaran di jurusan Tadris Bahasa Indonesia, IAIN Tulungagung. Penelitian ini didasari oleh fakta bahwa hampir tidak ada buku ajar yang secara khusus membahas tentang media pembelajaran bahasa Indonesia. Pada umumnya para Dosen dan Mahasiswa Tadris Bahasa Indonesia IAIN Tulungagung menggunakan buku referensi media pembelajaran secara umum. Hal ini membuat subtansi mata kuliah media pembelajaran bahasa Indonesia kurang dapat dipahami dengan rinci. Metode yang digunakan dalam penelitian ini mengadaptasi model penelitian dan pengembangan Borg dan Gall. Hasil penelitian dan pengembangan ini berupa buku ajar mata kuliah media pembelajaran bahasa Indonesia. Buku ini diujicobakan kepada tim ahli, dosen, dan para mahasiswa. Terdapat dua ahli untuk menguji coba buku ini yaitu ahli media dan ahli materi bahasa Indonesia. Berdasarkan hasil uji coba diperoleh hasil bahwa buku ini efektif digunakan dalam perkuliahan media pembelajaran bahasa Indonesia. Hal ini juga terlihat dari perbandingan hasil prates maupun pascates setelah menggunakan buku ajar terhadap mahasiswa. Namun, terdapat beberapa revisi untuk memperbaiki isi maupun tampilan buku ajar agar lebih layak digunakan. Revisi dilakukan pada aspek variasi latihan dan tampilan layout bahan ajar. Selain itu, ada penambahan materi tentang jenis-jenis media. Hal ini agar memperkaya wawasan mahasiswa terkait macam media pembelajaran.

Kata kunci: buku ajar; media pembelajaran bahasa Indonesia; Mahasiswa TBIN IAIN Tulungagung
\end{abstract}

\begin{abstract}
This research is a research to develop textbooks for learning media course in Indonesian Language Tadris Department of IAIN Tulungagung. This research is based on the fact that there is almost no textbook specifically discuss Indonesian language learning media. Indonesian Language Tadris Departement lecturers and students of IAIN Tulungagung commonly use reference books for learning media in general. This makes the substance of the Indonesian language learning
\end{abstract}


media course less comprehensible. The method used in this study adapts the research and development model of Borg and Gall. The results of this research and development are in the form of textbooks for Indonesian language learning media. This book was tested on a team of experts, lecturers, and students. There are two experts to test this book, they are media experts and Indonesian language experts. Based on the trial results, it was found that this book was effectively used in Indonesian language learning media. This can also be seen from the comparison of pre-test and post-test results after using textbooks towards students. However, there are some revisions to improve the content and appearance of textbooks to make it more feasible to use. Revisions were made towards aspects of the exercises variation and layout feature of teaching material. In addition, there are additional materials about types of media. This is in order to enrich students' insights concerning with kinds of learning media.

\section{Keywords: textbooks; Indonesian language learning media; Students of TBIN IAIN Tulungagung}

\section{PENDAHULUAN}

Mata kuliah media pembelajaran bahasa Indonesia merupakan salah satu mata kuliah prasyarat bagi mahasiswa jurusan Tadris Bahasa Indonesia, Fakultas Tarbiyah dan Ilmu Keguruan, IAIN Tulungagung. Mata kuliah ini memang tergolong masih baru seiring dengan pertumbuhan jurusan Tadris Bahasa Indonesia di lingkungan IAIN Tulungagung. Dengan adanya, mata kuliah ini diharapkan mahasiswa sebagai calon guru bahasa Indonesia dapat menambah wawasan mengenai teori media pembelajaran dan dapat mengaplikasikan teori yang ada dalam wujud media pembelajaran bahasa Indonesia yang inovatif. Target yang ingin dicapai dalam mata kuliah media pembelajaran bahasa Indonesia adalah mahasiswa mampu mengembangkan media pembelajaran bahasa Indonesia yang kreatif dan inovatif sesuai dengan jenjang satuan pendidikan, kompetensi dasar, dan aspek materi pembelajaran.

Asih (2016, p. 201-202) menyatakan bahwa media pembelajaran bahasa Indonesia merupakan segala sesuatu yang digunakan untuk menyalurkan pesan dan dapat merangsang pikiran, perasaan, perhatian, dan kemauan siswa pada mata pelajaran bahasa Indonesia sehingga dapat mendorong terjadinya proses belajar yang lebih efektif dan efisien dalam diri siswa.

Keberadaan media pembelajaran bahasa Indonesia menjadi hal yang penting. Hal ini karena media merupakan salah satu komponen untuk menyalurkan pesan dalam pembelajaran bahasa Indonesia. Selain itu, media pembelajaran dapat menarik perhatian siswa dalam proses belajar bahasa Indonesia. Oleh karena itu, adanya mata kuliah media pembelajaran bahasa Indonesia menjadi landasan bagi mahasiswa sebagai calon guru untuk mengembangkan media pembelajaran bahasa Indonesia untuk mendukung aktivitas belajar-mengajar.

Sarana penunjang dalam mata kuliah media pembelajaran bahasa Indonesia mutlak dibutuhkan untuk membantu pencapaian target pembelajaran. Salah satu sarana yang dapat dihadirkan adalah buku ajar mata kuliah media pembelajaran bahasa 
Indonesia. Menurut Prastowo (2011, p. 169) keberadaan buku ajar merupakan bagian yang tidak terpisahkan dari proses pembelajaran yang berlangsung di berbagai institusi pendidikan. Buku ajar merupakan bagian penting dari kegiatan pembelajaran. Fungsi buku ajar dapat sebagai bahan referensi atau bahan rujukan oleh peserta didik, sebagai bahan evaluasi, sebagai alat bantu pendidik dalam melaksanakan kurikulum, dan sebagai salah satu penentu metode atau teknik pengajaran yang akan digunakan pendidik. Oleh karena itu, buku ajar menjadi hal yang perlu dihadirkan dalam perkuliahan media pembelajaran bahasa Indonesia. Hal ini digunakan untuk bahan rujukan mahasiswa dan dosen, sebagai bahan evaluasi, dan penentu metode dan teknik perkuliahan media pembelajaran bahasa Indonesia.

Berdasarkan hasil observasi dan studi pendahuluan yang dilakukan oleh peneliti melalui wawancara kepada dosen pengajar dan penyebaran angket analisis kebutuhan kepada mahasiswa diperoleh beberapa kesimpulan. Pertama, buku ajar mata kuliah media pembelajaran bahasa Indonesia masih belum tersedia di IAIN Tulungagung. Bahkan, buku tentang media pembelajaran bahasa Indonesia belum diperjual-belikan di pasaran, baik toko buku online maupun offline. Kedua, buku yang paling sering dijumpai oleh dosen maupun mahasiswa serta peneliti adalah buku tentang media pembelajaran secara umum. Ketiga, buku media pembelajaran tersebut tidak berfokus kepada mata pelajaran bahasa Indonesia.

Namun, peneliti pernah menjumpai satu e-book membahas tentang media pembelajaran bahasa Indonesia yang diterbitkan oleh Pusat Pengembangan dan Pemberdayaan Pendidik dan Tenaga Kependidikan Bahasa, Kementerian Pendidikan Nasional pada tahun 2010 untuk pelatihan KKG. Hal ini, akhirnya menjadi satu-satunya acuan untuk materi media pembelajaran bahasa Indonesia. E-book berbentuk PDF tersebut menguraikan tentang garis besar dalam media pembelajaran bahasa Indonesia. Hal ini kurang sesuai dengan kompetensi dasar yang ada dalam mata kuliah media pembelajaran bahasa Indonesia di Jurusan Tadris Bahasa Indonesia, IAIN Tulungagung.

Berdasarkan uraian di atas, perlu dikembangkan sebuah buku ajar mata kuliah media pembelajaran bahasa Indonesia untuk Mahasiswa Jurusan Tadris Bahasa Indonesia, IAIN Tulungagung. Pengembangan buku ajar ini penting untuk menunjang mata kuliah media pembelajaran bahasa Indonesia. Hal ini bertujuan agar mahasiswa dapat menambah wawasan mengenai materi media pembelajaran yang berfokus pada mata pelajaran bahasa Indonesia. Selain itu, mahasiswa lebih terampil dalam mengaplikasikan pengetahuannya tersebut dalam wujud media pembelajaran yang bermanfaat dalam kegiatan belajar mengajar. Hal ini senada dengan pendapat Prastowo (2011, p. 26-27) bahwa buku ajar dapat membantu peserta didik dalam mempelajari sesuatu, memudahkan peserta didik dalam melaksanakan pembelajaran, dan menyediakan buku ajar yang sesuai dengan kompetensi yang ada.

Buku ajar mata kuliah media pembelajaran bahasa Indonesia yang dikembangkan sesuai dengan kebutuhan mahasiswa. Buku ajar ini juga menempatkan substansi pokok sesuai dengan standar yang ditetapkan oleh kurikulum DIKTI, dan disesuaikan dengan kompetensi lulusan, sehingga sesuai dengan target pencapaian mata kuliah media pembelajaran bahasa Indonesia di IAIN Tulungagung. Buku hasil 
pengembangan ini nantinya dapat membantu mahasiswa dalam mempelajari mata kuliah media pembelajaran bahasa Indonesia dan membantu tercapainya tujuan kurikulum Jurusan TBIN di IAIN Tulungagung.

Sebelum adanya peneitian ini, terlebih dulu ada penelitian yang berusaha mengembangkan bahan ajar media pembelajaran untuk mahasiswa di institusi dan jurusan yang berbeda. Misal, penelitian yang dilakukan oleh Djoko Hari Supriyanto, dkk. (2017) yang berjudul Pengembangan Buku Ajar Mata Kuliah Konsep Dasar IPA S1 PGSD Berorientasi Pembelajaran Quantum menghasilkan pengembangan buku ajar yang berorientasi pembelajaran quantum. Selain itu, penelitian Aan Nurhasanah (2017) yang berjudul Pengembangan Bahan Ajar Pendidikan Matematika I untuk Meningkatkan Kualitas Pembelajaran Mahasiswa PGSD Universitas Kuningan menghasilkan pengembangan bahan ajar untuk prodi PGSD.

Berdasarkan latar belakang yang telah dijabarkan di atas, rumusan masalah penelitian dan pengembangan ini dibagi menjadi dua, yaitu umum dan khusus. Rumusan masalah umum penelitian dan pengembangan adalah bagaimanakah menghasilkan buku ajar media pembelajaran bahasa Indonesia? Adapun rumusan masalah khusus dari penelitian ini sebagai berikut. (1) Bagaimanakah buku ajar media pembelajaran bahasa Indonesia yang terdiri dari materi buku ajar, penyajian buku ajar, bahasa dalam buku ajar? (2) Bagaimanakah keefektifan buku ajar media pembelajaran bahasa Indonesia dalam aktivitas perkuliahan?

\section{METODE PENELITIAN}

Penelitian yang dilaksanakan bertujuan untuk menghasilkan buku ajar mata kuliah media pembelajaran bahasa Indonesia yang layak dan efektif digunakan dalam perkuliahan. Berdasarkan tujuan tersebut, maka model penelitian dan pengembangan Research and Development (R\&D) yang diterapkan adalah model Borg dan Gall.

Penelitian dan pengembangan dengan model Borg dan Gall, secara umum memiliki sepuluh langkah dalam mengembangkan sebuah produk. Borg dan Gall menjelaskan sepuluh langkah tersebut, meliputi (1) melakukan penelitian pendahuluan, (2) melakukan perencanaan, (3) pengembangan draf produk, (4) uji coba ahli terhadap format produk yang dikembangkan, (5) revisi produk berdasarkan hasil uji coba pada tim ahli, (6) uji coba lapangan utama kepada subjek penelitian, (7) revisi produk yang dikerjakan berdasarkan hasil uji coba lapangan, (8) uji lapangan operasional setelah produk direvisi, (9) revisi produk akhir, dan (10) diseminasi dan implementasi (Tegeh, Jampel, Pudjawan, 2014, p. 7).

Penelitian dan pengembangan ini, mengadaptasi sepuluh prosedur penelitian dan pengembangan Borg dan Gall. Terdapat tujuh prosedur yang diaplikasikan dalam penelitian dan pengembangan ini. Tujuh langkah penelitian dan pengembangan yang diadaptasi dari model pengembangan Borg dan Gall diuraikan sebagai berikut. (1) Melakukan penelitian pendahuluan melalui kajian pustaka dan pengamatan kelas. Kegiatan penelitian pendahuluan bertujuan untuk memperoleh informasi terkait dengan buku ajar yang akan dikembangkan dan untuk mempelajari dan mendalami karakteristik materi yang akan dikembangkan ke dalam buku ajar yang direncanakan. 
(2) Melakukan perencanaan berupa penetapan produk dan partisipan. Produk yang akan dikembangkan adalah buku ajar mata kuliah media pembelajaran bahasa Indonesia, sedangkan partisipan adalah tim ahli, dosen, dan mahasiswa.

(3) Mengembangkan draf produk berupa buku ajar mata kuliah media pembelajaran bahasa Indonesia, meliputi materi perkuliahan, latihan-latihan, dan evaluasi. (4) Melaksanakan uji produk kepada tim ahli untuk memperoleh buku ajar yang layak sebelum diujicobakan di lapangan. Uji coba tim ahli ditujukan kepada ahli materi bahasa Indonesia dan ahli pengembangan media. (5) Melaksanakan revisi produk berdasarkan penilaian dari tim ahli. (6) Melaksanakan uji coba lapangan. Pada kegiatan tersebut, uji lapangan dilakukan terhadap partisipan yang sudah dipilih, yaitu dosen dan mahasiswa. (7) Melakukan penyempurnaan terhadap produk akhir berdasarkan hasil uji coba lapangan yang dilakukan.

Penelitian dan pengembangan yang dilaksanakan menggunakan teknik analisis data kualitatif dan analisis data kuantitatif. Analisis kualitatif digunakan untuk menganalisis data verbal. Sementara itu, analisis kuantitatif digunakan untuk menganalisis data nonverbal atau numerik.

Analisis kualitatif digunakan untuk menganalisis data verbal. Langkah-langkah analisis kualitatif, yaitu (1) mengumpulkan data verbal tertulis yang diperoleh dari hasil wawancara, angket, dan observasi. (2) Mentranskrip data verbal tidak tertulis dari hasil wawancara kepada dosen dan mahasiswa. (3) Menganalisis data dan merumuskan simpulan analisis sebagai dasar untuk melakukan tindakan terhadap produk yang dikembangkan.

Analisis kuantitatif digunakan untuk menganalisis data numerik. Bagian ini terdiri dari (1) analisis data uji coba produk dan (2) analisis skor prates dan pascates.

\section{HASIL DAN PEMBAHASAN}

\section{Penyajian Data}

Penelitian ini menghasilkan buku ajar mata kuliah media pembelajaran bahasa Indonesia. Buku ajar ini diperuntukkan untuk mahasiswa yang mengambil mata kuliah media pembelajaran bahasa Indonesia. Buku ini disusun berdasarkan analisis kebutuhan mahasiswa yang disebarkan melalui angket dan wawancara terhadap dosen mata kuliah media pembelajaran bahasa Indonesia. Data yang diperoleh dari analisis kebutuhan dikumpulkan dan diperoleh simpulan bahwa buku media pembelajaran bahasa Indonesia memang belum ada dan sangat dibutuhkan sebagai bahan referensi. Data yang diperoleh tersebut kemudian dijadikan pedoman untuk menyusun standar kompetensi, kompetensi dasar, dan indikator pencapaian mata kuliah media pembelajaran bahasa Indonesia. Di samping itu, referensi media pembelajaran secara umum juga digunakan sebagai dasar penyusunannya.

Setelah standar kompetensi, kompetensi dasar, serta indikator pencapaian mata kuliah tersusun, draf penyusunan buku ajar dibuat. Mulai dari bab pendahuluan hingga bab terakhir. Kemudian, menyusun satu per satu bab dalam buku ajar. Penyusunan bab dimulai dari pendahuluan, materi atau teori sesuai judul bab, dan latihan-latihan yang terkait dengan materi. Setelah itu, menyusun contoh atau ilustrasi produk media 
pembelajaran yang sesuai dengan judul bab. Contoh produk media pembelajaran bahasa Indonesia disesuaikan dengan jenjang SMP (Sekolah Menengah Pertama) dan SMA (Sekolah Menengah Atas). Mulai dari kelas, semester, kompetensi inti, kompetensi dasar, indikator, tujuan pembelajaran, hingga materi yang digunakan.

Materi media pembelajaran bahasa Indonesia dikembangkan dengan mengadaptasi materi media pembelajaran secara umum. Bab pertama memuat pendahuluan terkait pengantar perkuliahan media pembelajaran bahasa Indonesia. Bab kedua memuat materi hakikat media pembelajaran bahasa Indonesia. Bab ketiga memuat materi tujuan, fungsi dan manfaat media pembelajaran bahasa Indonesia. Materi ini untuk menjelaskan istilah tujuan, fungsi, manfaat media pembelajaran bahasa Indonesia kepada mahasiswa. Salah satu pendapat yang dimasukkan dalam bagian ini adalah fungsi media pembelajaran menurut Daryanto (2016, p. 8) yaitu media sebagai pembawa informasi dari sumber (guru) kepada penerima (siswa).

Selanjutnya, bab keempat memuat materi tentang jenis-jenis media pembelajaran. Materi ini mencantumkan jenis-jenis media pembelajaran yang ada secara umum, lalu disesuaikan dengan pembelajaran bahasa Indonesia. Jenis-jenis media pembelajaran ini penting dihadirkan dalam buku ajar ini. Hal ini karena materi tersebut dapat memberikan wawasan kepada mahasiswa tentang media yang dapat dimanfaatkan atau bisa dikembangkan untuk pembelajaran, terutama bahasa Indonesia. Hal ini sesuai dengan pendapat Wati (2016, p. 25) bahwa jenis-jenis media pembelajaran dapat memberikan wawasan kepada guru, sehingga guru dapat menggunakannya atau bahkan mengembangkannya.

Jenis-jenis media pembelajaran yang dapat digunakan dalam bahasa Indonesia, bukan hanya dalam bentuk benda yang bisa disentuh atau dipegang. Media proyeksi, multimedia, bahkan berbasis internet pun dapat digunakan untuk pembelajaran bahasa Indonesia. Hal ini memberikan pilihan yang cukup banyak bagi guru atau calon guru untuk dapat menentukan media yang cocok digunakan dalam pembelajarannya. Kustandi dan Bambang (2013, p. 29) mengelompokkan media menjadi empat yaitu teknologi cetak, audio-visual, berbasis komputer, teknologi cetak-komputer.

Bab kelima merupakan materi tentang pemilihan, pemanfaatan, dan pengembangan media pembelajaran. Materi ini juga penting untuk membekali guru, calon guru, maupun mahasiswa untuk dapat memahami kriteria pemilihan, pemanfaatan maupun pengembangan media pembelajaran. Bab keenam memuat contoh media dalam pembelajaran menyimak. Bab ketujuh memuat contoh media dalam pembelajaran berbicara. Bab kedelapan memuat contoh media dalam pembelajaran membaca, dan bab kesembilan memuat contoh media pembelajaran menulis. Pembelajaran bahasa Indonesia memuat empat keterampilan berbahasa seperti yang dijelaskan oleh Tarigan (2008, p. 2) keterampilan berbahasa dalam kurikulum di sekolah mencakup empat segi yaitu keterampilan menyimak, berbicara, membaca, dan menulis.

\section{Analisis Data}

Berdasarkan data hasil uji coba di lapangan, maka akan dianalisis data uji coba berdasarkan aspek materi, penataan penyajian, dan bahasa. Berikut ini dipaparkan (1) 
analisis data berdasarkan pengembangan materi dalam buku ajar mata kuliah media pembelajaran bahasa Indonesia, (2) analisis data berdasarkan pengembangan penataan penyajian dalam buku ajar, dan (3) analisis data berdasarkan bahasa dalam buku ajar mata kuliah media pembelajaran bahasa Indonesia.

Data yang diperoleh dari uji coba buku ajar disajikan untuk dianalisis sebagai dasar pemantapan buku ajar. Kritik dan saran yang bersifat membangun dari subjek coba dijadikan dasar untuk merevisi komponen-komponen yang terdapat dalam buku ajar ini. Analisis data berdasarkan aspek materi dibagi menjadi tiga pokok bahasan berdasarkan subjek uji cobanya. Subjek uji coba tersebut antara lain: ahli, dosen mata kuliah media pembelajaran bahasa Indonesia, dan mahasiswa.

Analisis data uji coba buku ajar terhadap pakar/ahli mengenai materi dalam buku ajar yang dikembangkan menunjukkan bahwa ahli pembelajaran memberikan penilaian sangat sesuai, sangat mudah, dan tepat. Analisis data uji coba buku ajar terhadap pakar/ahli mengenai materi dalam buku ajar yang dikembangkan menunjukkan bahwa ahli media memberikan penilaian sesuai, akurat, dan menarik.

Analisis data uji coba buku ajar terhadap dosen mata kuliah media pembelajaran bahasa Indonesia mengenai materi dalam buku ajar yang dikembangkan mendapatkan penilaian yang sesuai, menarik, dan cukup komunikatif. Analisis data uji coba buku ajar terhadap mahasiswa, pada aspek kemenarikan ragam latihan mendapatkan penilaian dari 20 orang mahasiswa. Dari 15 orang mahasiswa, 3 orang memberi penilaian menarik dan 2 orang memberi penilaian cukup menarik. Dari data ini, dapat diambil kesimpulan bahwa ragam materi yang disajikan dalam buku ajar sudah menarik.

Dari keseluruhan hasil uji coba kepada pakar/ahli, dosen, dan mahasiswa tentang aspek materi dalam buku ajar ini diperoleh simpulan bahwa materi dalam buku ajar ini sudah sesuai, cukup menarik, dan sudah komunikatif. Oleh karena itu, materi dalam buku ajar ini tidak mengalami revisi.

Berdasarkan data yang dihimpun dari hasil uji coba pakar/ahli mengenai penataan penyajian dalam buku ajar yang dikembangkan menunjukkan bahwa ahli menilai sangat sistematis, sangat konsisten, sangat logis, dan utuh penataan penyajian dalam buku ajar. Sedangkan, data yang dihimpun dari hasil uji coba pakar/ahli mengenai penataan penyajian dalam buku ajar yang dikembangkan menunjukkan bahwa ahli menilai sangat sistematis, sangat konsisten, sangat logis, dan utuh penataan penyajian dalam buku ajar.

Analisis data uji coba buku ajar terhadap dosen mata kuliah media pembelajaran bahasa Indonesia mengenai penataan penyajian dalam buku ajar yang dikembangkan mendapatkan penilaian yang sistematis, konsisten, logis, dan utuh. Sedangkan, analisis data uji coba buku ajar terhadap mahasiswa penataan penyajian dalam buku ajar yang dikembangkan menunjukkan bahwa mahasiswa menilai jelas penataan penyajian yang disajikan. Berikut data temuan dari hasil uji dari 20 mahasiswa: pada aspek kejelasan kalimat perintah (petunjuk kerja) latihan, 3 orang memberi penilaian kurang jelas, dan 17 orang memberi penilaian sudah jelas.

Dari keseluruhan data temuan hasil uji coba kepada pakar/ahli, pengajar/guru, dan mahasiswa tentang aspek penataan penyajian dalam buku ajar membuktikan bahwa pada penataan penyajian yang disajikan terdapat jelas dan urut serta logis. Terdapat 
catatan untuk menambah layout agar tampilan lebih menarik. Analisis data tentang ragam latihan dalam bahan ajar menunjukkan bahwa ragam latihan yang dikembangkan dalam bahan ajar ada yang harus direvisi. Revisi penataan penyajian buku ajar dilakukan agar buku ajar diperbaiki.

Berdasarkan data yang dihimpun dari hasil uji coba pakar/ahli mengenai bahasa dalam buku ajar yang dikembangkan menunjukkan bahwa ahli menilai cukup komunikatif, sangat jelas, sesuai EBI. Sedangkan, data yang dihimpun dari hasil uji coba pakar/ahli mengenai bahasa dalam buku ajar yang dikembangkan menunjukkan bahwa ahli menilai cukup komunikatif, sangat jelas, sesuai EBI.

Analisis data uji coba buku ajar terhadap dosen media pembelajaran bahasa Indonesia mengenai bahasa dalam buku ajar yang dikembangkan mendapatkan penilaian yang sangat komunikatif, sangat jelas, dan cukup sesuai EBI. Sedangkan, analisis data uji coba buku ajar terhadap mahasiswa mengenai bahasa dalam buku ajar yang dikembangkan menunjukkan bahwa mahasiswa menilai cukup mudah dipahami dan jelas bahasa yang digunakan.

Berdasarkan hasil analisis SPSS diperoleh skor rata-rata prates mahasiswa adalah 50,73 dengan standart deviasi 6,389. Sementara itu, skor rata-rata pascates setelah penerapanan buku ajar adalah 85,82 dengan standart deviasi 6,306. Dari perhitungan data tersebut dapat diketahui bahwa skor pascates 85,82 lebih besar daripada skor prates $50,73(85,82>50,73)$.

Selanjutnya berdasarkan uji-t diperoleh $t_{\text {hitung }} 11,112$ dengan $\mathrm{P}=0,00$ jadi $(\mathrm{P}$ $<0,01)$. Berdasarkan data tersebut peserta didik yang mendapat skor prates rendah mendapatkan skor pascates tinggi. Dengan demikian terdapat perbedaan skor prates dan pascates sehingga terdapat perbedaan yang siginifikan antara skor prates dan pascates. $(\mathrm{P}<0,01)$ jadi produk ini efektif untuk digunakan dalam perkuliahan.

\section{Revisi Produk}

Revisi produk berfungsi untuk memperbaiki hal-hal yang kurang sesuai dalam buku ajar yang telah dibuat. Uji coba buku ajar dilaksanakan setelah melakukan kegiatan uji coba pada subjek ahli, dosen mata kuliah media pembelajaran bahasa Indonesia, dan mahasiswa.

Data uji coba bahan berupa data verbal tulis yang diperoleh dari koreksi dan catatan yang tertulis dalam instrumen uji coba dan produk yang diujicobakan. Data verbal lisan diperoleh dari wawancara atau dialog dengan ahli dan dosen. Data dari penelitian kemudian dihimpun dan dipelajari dengan seksama dan disajikan secara terpisah untuk menyesuaikan dengan setiap rumusan masalah bahan ajar yang dikembangkan. Data tersebut mengarahkan peneliti untuk merevisi atau tidak merevisi buku ajar yang dikembangkan.

Revisi produk digunakan untuk memperbaiki isi buku ajar yang kurang sempurna mengacu dari saran ahli/pakar, dosen, dan mahasiswa. Berdasarkan angket yang telah diujicobakan kepada dosen dan ahli, diperoleh simpulan sehingga tidak diperlukan revisi. Revisi produk digunakan untuk memperbaiki isi buku ajar yang kurang sempurna mengacu dari saran ahli/pakar, dosen, dan mahasiswa. Berdasarkan angket yang telah 
diujicobakan kepada ahli, dosen dan mahasiswa, revisi produk yang dilakukan meliputi dua aspek.

Revisi produk yang dilakukan pada dua aspek, yaitu (1) variasi latihan, (2) tampilan layout. Pada aspek keinteraktifan latihan, saran yang diberikan dari uji coba produk di lapangan kepada dosen yaitu bentuk latihan diberi tambahan latihan yang melatih kerja sama mahasiswa (kelompok). Oleh karena itu, produk perlu direvisi. Pada produk awal, tidak ada bentuk latihan yang mengharuskan mahasiswa bekerja sama (berkelompok). Setelah dilakukan revisi, latihan dalam buku ajar ditambah dengan bentuk latihan yang melatih kerja sama antarmahasiswa (berkelompok untuk berdiskusi sesuai materi).

Sedangkan aspek tampilan, berdasarkan uji coba yang dilaksanakan diperoleh simpulan bahwa layout perlu ditambah dalam buku agar penataan penyajian terlihat menarik dan tidak monoton. Pada tabel berikut disajikan ikhtisar revisi produk yang berasal dari uji coba di lapangan.

\section{Tabel 1: Ikhtisar Revisi Produk berdasarkan Aspek Penataan Penyajian}

\begin{tabular}{|c|c|c|c|}
\hline Aspek & Produk awal & Saran & Produk akhir \\
\hline Variasi latihan & $\begin{array}{l}\text { Tidak adanya bentuk } \\
\text { latihan yang } \\
\text { mengharuskan } \\
\text { mahasiswa bekerja sama } \\
\text { (berkelompok). }\end{array}$ & $\begin{array}{l}\text { Bentuk latihan diberi } \\
\text { tambahan latihan yang } \\
\text { melatih kerja sama } \\
\text { mahasiswa } \\
\text { (kelompok). }\end{array}$ & $\begin{array}{l}\text { Ditambah dengan } \\
\text { bentuk latihan yang } \\
\text { melatih kerja sama } \\
\text { mahasiswa. }\end{array}$ \\
\hline $\begin{array}{l}\text { Tampilan } \\
\text { Layout }\end{array}$ & $\begin{array}{l}\text { Belum ada tampilan } \\
\text { layout yang memadai }\end{array}$ & $\begin{array}{l}\text { Sebaiknya tampilan } \\
\text { layout ditambah-kan } \\
\text { untuk menarik } \\
\text { mahasiswa }\end{array}$ & Ditambahkan layout \\
\hline
\end{tabular}

Revisi produk digunakan untuk memperbaiki isi buku ajar yang kurang sempurna mengacu dari saran ahli/pakar, dosen, dan mahasiswa. Berdasarkan angket yang telah diujicobakan kepada ahli, dosen dan mahasiswa, diperoleh simpulan penggunaan bahasa sudah komunikatif, jelas, dan sesuai EBI. Jadi tidak perlu dilakukan revisi.

\section{SIMPULAN}

Sarana penunjang dalam mata kuliah media pembelajaran bahasa Indonesia mutlak dibutuhkan untuk membantu pencapaian target pembelajaran. Salah satu sarana yang dapat dihadirkan adalah buku ajar mata kuliah media pembelajaran bahasa Indonesia. Oleh karena itu, perlu dikembangkan sebuah buku ajar mata kuliah media pembelajaran bahasa Indonesia untuk Mahasiswa Jurusan Tadris Bahasa Indonesia, IAIN Tulungagung. Pengembangan buku ajar ini penting untuk menunjang mata kuliah media pembelajaran bahasa Indonesia. Hal ini bertujuan agar mahasiswa dapat menambah wawasan mengenai materi media pembelajaran yang berfokus pada mata pelajaran bahasa Indonesia. Selain itu, mahasiswa lebih terampil dalam 
mengaplikasikan pengetahuannya tersebut dalam wujud media pembelajaran yang bermanfaat dalam kegiatan belajar mengajar.

Produk buku ajar ini meliputi 9 bab yang terdiri dari bab 1 pendahuluan, bab 2 hakikat media pembelajaran bahasa Indonesia, bab 3 tujuan, manfaat, dan fungsi media pembelajaran bahasa Indonesia, bab 4 Jenis-jenis media pembelajaran bahasa Indonesia, bab 5 pemilihan, pemanfaatan, dan pengembangan media pembelajaran bahasa Indonesia, bab 6 media pembelajaran menyimak, bab 7 media pembelajaran berbicara, bab 8 media pembelajaran membaca, dan yang terakhir bab 9 adalah media pembelajaran menulis.

Hasil analisis data menunjukkan bahwa buku ajar ini efektif dalam perkuliahan. Selain itu, ada beberapa komponen dan hal yang harus direvisi berdasarkan penilaian dari para ahli dalam uji coba tahap pertama. Setelah buku ajar direvisi, diujicobakan kepada mahasiswa dan dosen dalam perkuliahan. Dari uji coba tersebut juga diperoleh saran-saran dan masukan untuk memperbaiki buku ajar. Setelah buku ajar direvisi pada tahap akhir, buku ajar siap untuk digunakan khalayak.

\section{DAFTAR RUJUKAN}

Asih. (2016). Strategi Pembelajaran Bahasa Indonesia. Bandung: Penerbit Pustaka Setia.

Asyhar, R. (2011). Kreatif Mengembangkan Media Pembelajaran. Jakarta: Gaung Persada Press.

Daryanto. (2016). Media Pembelajaran: Edisi Revisi. Yogyakarta: Penerbit Gava Media.

Kustandi, C \& Bambang S. (2013). Media Pembelajaran; Manual dan Digital Edisi Kedua. Bogor: Penerbit Ghalia Indonesia.

Nurhasanah, A. (2017). Pengembangan Bahan Ajar Pendidikan Matematika I untuk Meningkatkan Kualitas Pembelajaran Mahasiswa PGSD Universitas Kuningan. Diakses pada 1 Maret 2018, dari http://ejournal.upi.edu/index.php/eduhumaniora/article/download/7017/4892

Prastowo, A. (2011). Panduan Kreatif Membuat Bahan Ajar Inovatif. Yogyakarta: Diva Press.

Tarigan, H. G. (2008). Menyimak sebagai Suatu Keterampilan Berbahasa. Bandung: Penerbit Angkasa.

Tegeh, I Made, Jampel I., \& Pudjawan, K. (2014). Model Penelitian Pengembangan. Yogyakarta: Graha Ilmu.

Supriyanto, D., Ibrahim, M., \& Widodo, W., (2017). Pengembangan Buku Ajar Mata Kuliah Konsep Dasar IPA S1 PGSD Berorientasi Pembelajaran Quantum. Diakses pada 6 Maret 2018, dari http://journal.unesa.ac.id/index.php/PD.

Wati, E. R. (2016). Ragam Media Pembelajaran. Jakarta: Kata Pena. 